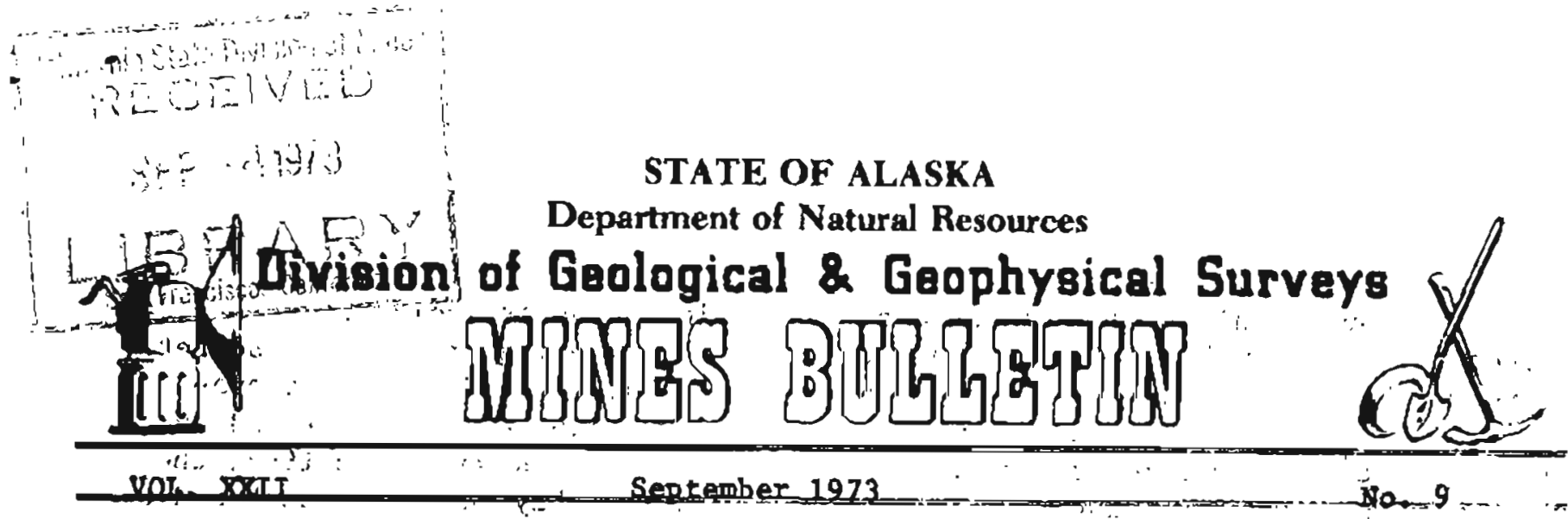

P. 0. $186 x 8000 \%$

int $\quad$ ! !

$\therefore \cdot \because+$

. 3.

College, Alaska 90701

Published to Accelerate the Development of the Mining Industry in Alaska

Willam A. Egen - Covemor

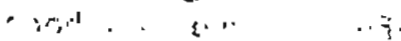

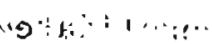

1.

Charles F. Herbert - Commissioner

Donald Ci Hartinạ - State Geologist

$\therefore ; 3$

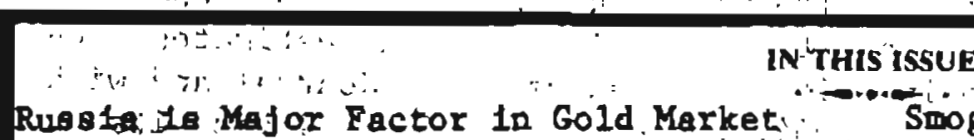

U.S. Position as Phosphate Exporter Weakens

Let's Go Prospecting

\$8-\$12 S1lver Pr1ces are Predicted by Currency Authorlty

Smog Control Needa could Boost Demend

for Platinum, Bureau Report Notes

Divialoa Open-File Reports Avallable

New D́tolision Report

Metalg Market

Wistis in in

H. RUSSIA IS MANOR FACTOR MN COLD MARKET,

BUT' TEAT'S ALL ANIONE CAN BE SURE OF

(The Wall street Journal)

$\because$ LONDoin - A tip" to gold speculators: If you have a frlend at the CIA, be nice to him. If you don't have such a friend, find one.

te will undoubtedly have the best clues to the blggest mystery hanging over the wotld gold markets--the reserves; production and seling plans of the Sovlet Union.

Many people think that Soviet gold production last year amounted to about seven mililon troy ouncer; or íl6x of wotld output. Many people think that Sotiet gold reserves total neatiy 58 militon ounces, or nearly $5 \%$ of world imonetary gold reserves. Some people even thlnk they know it costa the Russtans an.". average of about $\$ 70$ an ounce to produce gold.from the frozen Sibertan wastes, the remote province of Uzbekiatin or other areas.

But only' a few töp Sov1et offictals really know for oure: And while, they aren't telling, 'western'estimateg have been aubject to some groso revisions in the last decade.

The only direct Westerth knowledge of Soviet gold comes when it is oold on

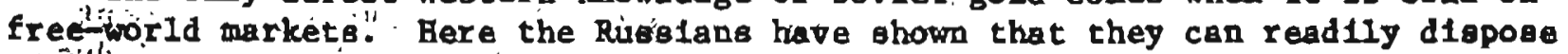
of éfbugh gold at fing given time to move world prices suarply - - though probably never enough to matipulate the market for very long.

GOLDER "GRATN

Soviet esles are est1mated at 6.1 milion ounces last year-about $13 x$ of

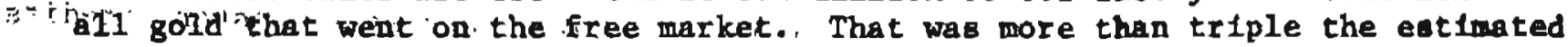
1.9 million ounces sold by Moscow in 1971. Rlalng gold prices and the need to pay for massive grain Imports provided the blggest gtimuli to the Russtans to unload more then 85\% of thelr 1972 production, bullion dealera say." 
The Soviet Union last published offlcial flgures on 1ta gold stock in 1934; since then, Moscow has been keeplag the subject a closely guarded state secret. Throughout the 1950s and early 1960s, Western estimates put Sovlet gold production at anything between 8.8 million and 19.3 million ounces a year and put reserves at 112.5 mililon to almost 290 militon ounces. However, in 1964, the CIA published a sharp downward reviston, belleved possibly to have been based on documents supplied by the Soviet defector, Col. Oleg Penikorsky. The new est1mates placed production at 4.3 million to 4.9 million ounces a year, well below the level of then-current sales. Reserves were put at 70.7 million to 85.2 mililion ounces.

Using these figures as a base, the most comprehenglve and up-to-date esti-: mates come from Michael Kaser. He is af Oxford University professor who has beed producing annual studies of Sovlet gold for the last three years for Consolidated Gold Flelds Ltd., a London-based company with wide South African press reports on the gold-mining industry; he puts these together with past CIA eatimates published in the U.S. Department of the Interfor's Bureau of Mines Journal and with reports of Western bullion dealers. (In 1964, the CIA stopped publishing Its estimates--which is why you now need a friend at the CIA.) His calculation of the roughly 70 -an-ounce average cost of producing gold in the Soviet union is carefully worked backward from reporta of wholegale prices paid by the Soviet jewelry industry to the ministry that runs the gold mines.

\section{THE RIVIDING LINE}

The Importance of the figure is that it marks the theoretical dividing line at which the Soviet Union's intentions and the character of 1ts activity in the world gold market change. For Instance; at prices less than $\$ 70$ an ounce, the Russians could be expected to sell gold grudgingly at a loss for hard currency to pay for imports from the ilest.

Revilews of the 1972 gold market published by London bullion dealers .hbow that what the Russians do-or what Western speculators think they are dolag-has a major Impact on the market. For example, "renewed sales from the Soviet Un1on," along with other factors, caused stability in the market from January tbrough early Apr1l of last year, says Samuel Montagu o Co., London merchant bankers that trade actively in the gold market.

However, in mid-Apr $11 ;$ the report adds, "the U.S.S.R. temporar11y suspended Its.gales" at the same time that reports circulated of a decilne in South African outpit: These factors gave rlse to a spurt In. the gold price "unprecedented since the end of World War II," the report says.

In August, the report goes on, word that "the U.S.S.R. would have to sell large quantitles (of gold). to flnance 1 ts purchases of wheat...led tola sharp fall in the price" of gold from record highs. Subsequent Soviet withdramal from the market sparked a rally, Samuel Montagu says.

No one knows, of course, what the Russians will do this year. But bullion dealers estimate that they sold at a rate of 643,000 to 964,500 ounces a month In the first half, well ahead of a year earlier. The rising price is an inducement to Soviet sales $f . ;$ two reasons, Prof. Raser suggests. Rirst, there 1s obviously more hard cash to be ralsed per precious ounce. But also, as the higher price swells the value of Soviet reserves, It may lead Moscow to feel eafer In: parting whth some of those reserves.

At the same time, Prof. Raser adds, increasing Soviet access to Westera credito relteves presiure on the Russlans to sell gold for hard currency to pay for imports. And that gives them even more freedom to play the market when and as they like. 

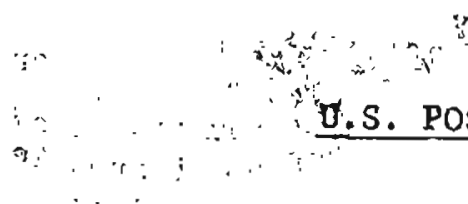

WORLD MARKETS FOR PHOSPHATE

WILL TURN TO SOURCES OUYSIIDE WHE

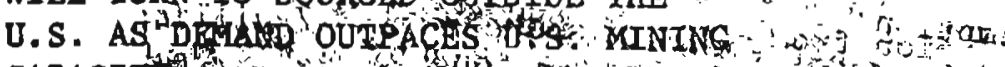

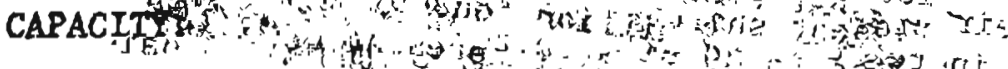

$$
\text { Ant }
$$

(Jute $2.5 ; 1973$ )

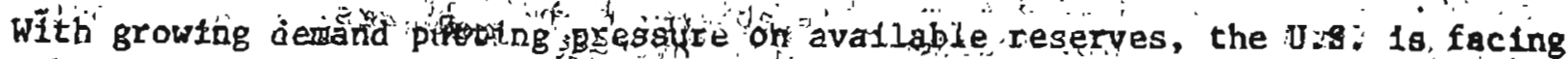

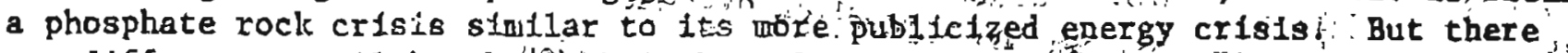

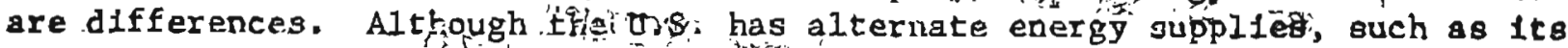
vast coal and shale resserves and 1 systy potental, there are no alternatives for phosphate rock. And, although ư

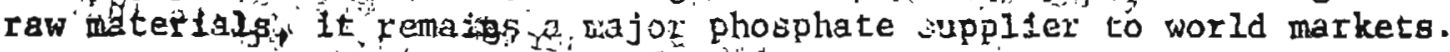

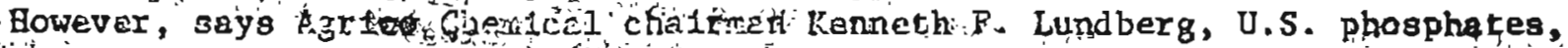

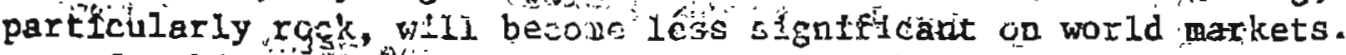

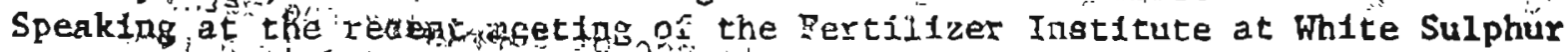

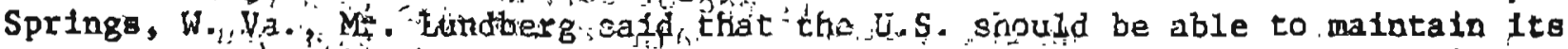

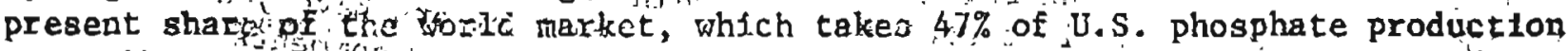
as rock' and 'upgradet products ard another $11 \%$ in the form of agricultural products; until 1980. After that, phosphates from such sources as Morocco, the U.S.S.R., Iunts1a, Algeria, Jordan, Sy,ia, Egypt, Togo, Spanlsh, Sahara, Angola, Australla, and Perul will have to take up the sleck. "At some point in the future," Mr. Lundbere says, "th.e U.S. will be a net importer of phosphate rock."

Desplte the glocoiy ontlook for thospinate rock and despite predictions that the U.S. phosphate iudustry will. 3 tixt gotog downhill in the mid-1980's, Mr. Lundberg ts optimlat1a. He thinke thai technology end economica can make a lot of difference between now and 1985: : We potnts cut that U.S. phosphates can be exported in many fozriö; from rock to zood, anc that the outlook for U.S. agriculture never has been brighter.

Last yeat, $19 \%$ of U.S. dcsnst:c phesphate consumptior was exported 1n.the

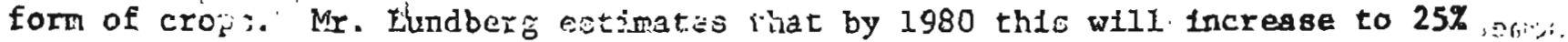
and will require an additionai 3 milijon toire of zock. Another 5.5 million tons i: more w11l be reeded for crops that $r .11$ be grown and consumed domestically. Thus, "domegtile demainf alone for phosphate roc: wili increase from last gear!s

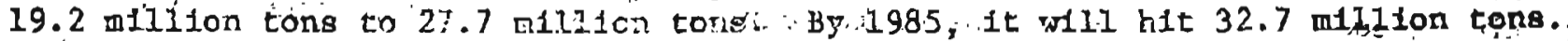

In addition to the phosphrtes expoted as crops, another $23 \%$ of total.U. phosphte exports move as wi-gizaded phosphate rrociucts. Th1s percentage 1s certa'tin to 1 astease," he says, as higher costs of inpening up wines make upgrading more profstable.

Meantilie, for the balarce of 1973 and 1974, rouk exports will be under

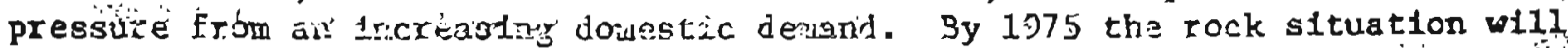
tmprove. New mizing capacity te cxpecter to cove on stream, and Mr. Lundbers says that the iJ.S. can'particlpate in a growing world market through 1980. However, if' the U.S.' is to 'maintain 1te present share of the world market for rock and phdsphate prdausts througt. 1985, th will need an additional i2 mill1on, ; tons of new uling duactity just Eur experts.

He estiwates"that about 27 militon tons of $\ldots$ te: mining capacity will be In operation by 1985 ! But the concemplated drop of 12 milition tons as a result of depleted reserves will put the net inarease at only $15 \mathrm{million}$ tons. And by then, iccreasing domestic deand wil force tise industry to withoraw rock from the export intilet.

Fortunetely; world minirg catiefty whych tataled ilo million tons last year, is on the threshold cs arbsiantial growth, according to Mt. Lundberg. 
He expects world capacity to reach 133 million tons by 1975,159 million tons by 1980 , and 180 millions tons by: 1985 . Of the total 70 milition ton Increase profected through 1985, he says 28 million tons will be In Africa, 10 million tons in the U.S.S.R., 15 million tons in Florida and North Carolina, and 17 million tons in other countries.

In 1970 worldwide rock consumption from non-U.S. sources was 57 million tons. If U.S. producers hold their present share of the world market, the demand for non-D.S. sources will increase to 89 million tons by 1980 . And any shortfall in the U.8. Industry's abiltty to hold its present world position w11. further increase the demand on overseas producers.

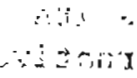

(Editor's Note:). The folfowing is the second of a serles of guest articles gubmitted to The M1n1ng:Record by Arden L. Lasson, geolog1st, Mult Metals Inc.

The flrst step in meeting our challenge of supplying the metals of tomorrow is to flad new mines. The flrst step in finding a new mine is a prospecting trip. I am quite certain that everyone of you, small miners have your own, Ideas. on how and where to go prospecting. I don't think that my comments will astound you, but perhaps you can apply. some of them to your own pet area.

I. Ibelleve that you can ldentify two broad methods of prospecting, a random. method and a sctentific.method. I would say that a person using the random. method:has a decreasingly small chance of finding a new mine. However, this is the method by which:most of our base metal, mines were found. In this method a person takes his rock pick or fightng rod or hunting rifle and takes off fnto. parts unknown to see what he can see. The main problem involved here is that he Isn!'t the first person to do this at h1s place. Thus the chances of finding something by kicking over a rock are rather small. However, he may stumble across someone else's prospect pit that was dug many years ago and thereln find something that is of value now that wagn't when the p1t was dug. Thus there is stili: a place for this method.

The scleptiftc method of prospecting is rather painstaking but is the method by which we will find the majority of our new mines. This is the method that the big mining companies use at considerable, expense. Now the small miner can't affard to go to much expense, so how does he use this method? To answer this, first, I had better explain exactiy what I mean by the scientific method.

This method could also be called an Indirect method as opposed to a direct method where you find the mine by plcking up a chunk of ore. In the lodirect method you use your head a little bl.t. Suppose that you were out looking over a forested hillside and you noticed a line of big trees, each one of them showlag effects of being struck by lightning. Now don't just sit there and say 1sn't that interesting; go over and see if you can determine why. I know of a large fluorite veln that was traced in exactly this manner. Either the vein matter was very nourishing to the trees and they grew taller, or the veln 1toelf was a better conductor than the surrounding rock and thus attracted the lightning strikes through the trees. In any event, the miners who noticed this phenomenon were able to develop their mine much easter than they would have otherwise.

There are:quite a few indirect methods that the small miner can use without spending much money. The oldest and most overlooked 1s the gold pan. A great many of our blg mining districts were found with the gold pan. Among them are 
Leadvilie and the Constock. However, the Comstock could have been found several years gooner than it was had someone been fortunate enough to Identify the strange black sand that kept clogging up the riffles in the slulce boxes (it was argentite silver).

A very new mine in Colorado could also have been found by the duse of ingold pan. Assoclated.with the Orad and Henderson molybdenum deposits of Climax is some tungsten. Had an 1ndividual been so fortunatio to analyse the black sand obtalned by panning in Clear Creek in Denver, he would have noticed that it was anomalous in tungsten compared with the other streams in the area. Had this individual foljowed the stream, panning and analyzing all of the large tributarles he would have eventualiy found hingelf at Urad by followlag the tun'gstend.

So, haw does the small miner prospect for minerals other than gold with a gold pan? Suppose you are in Montana and want to find tungsten:. Take yout pan (I have used a ple plate and a hubcap!) and a portable blacklight and otart panning otreams in your area of interest.

When you get your concentrate, use your blacklight to check for scheellite'.

If If you want to spend a little money, have the concentrate assayed for tungsten. Then follow the tungsten home.

use your pan regulariy in prospecting; examine the heavy ginerals with a handlens... often you can tell quite a lot about rock types this way in any area thatis completely covered by forest. You can save a sample of the heavy minerals for later analysis, but be sure to label them as to where you got 1t. A person can spend one day panning streams in an area, coveritg many square miles of drainage basins, and later have the assays to tell you what basin to go look at in toore detall. Many ore deposits leave their fingerprints in the heavy minerals of the "otreams draining them.

Most Indirect methods used by the large companies involve detalled trace :element workiby competent chemists. Sometimes, a very simple observation in the fleid would do: the same thing. I remember a silver property that carried a little bit of:rselendum. There 18 a certain flower whose color ts normally white, but :when there is a trace of selenlum around, the flower lis violet, becoming darker. whth more selenium. I; could actually trace. The silver vetns on this property by followlng the darkest violet flowers! A detalled geochemical samping program could not have done better. My point is, don't overlook the obvious. Fortunately the omall miner 18 receptive to new ldeas and also a very good observer. So when you go our prospecting, look closely at the trees, grasses, cactus, flowers as well as the rocks. Ifsten to whit they are trying to tell you.

I know that each of you has heard the saying about follow thet ore even if it r.goes up a tree. That same saying can be applied to answer the question of where to go prospectingio, I firmy believe that each new mine that will be found by the small miner wtif be near an area where' someone "has found ore of some kind before. The geologists of the blg companies will find new ore deposits in virgin country, but we smal miners will not. We can not afford the oophisticated-methods needed nor do we spmprehend the geologle reasoning involved. However, we will find our sharge, $\cdots$, i.:

Start your prospecting trip in an area where you know there is minerailzation, then work out from it. Perhaps you can work bétweén two mining campis, trging to find a pasalbie connectfon in ifieralization. 'then someone made a strike; he had plenty of pals looking right around him for another oide, but thelr efforts:decreased as the distance from the strike decreased." The chance of finding Bomet thing on the doorstep of another mine is not too good, but the chande of finding somethingubetween two mines on the same trend is much better.

Before. I. algn off; let me mention a bit on my next subject, proper sampling. Take your samples and the very. flrst thing, put them in a sack and label it as, to 
where it came from and what 1t 1s. You know very well that the sample that you forgot to label wil be the best one!

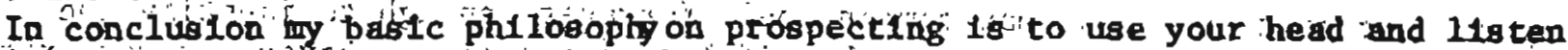
to Mother Nature. Sometimes we get too educated and milas the obvloug Good luck!

Next: Proper gampling

\section{\$8-\$12 SILVER PRICES ARE PREDECTED BY CURRENCY AUTHORCTR}

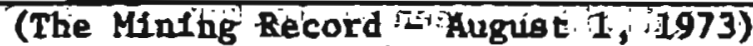

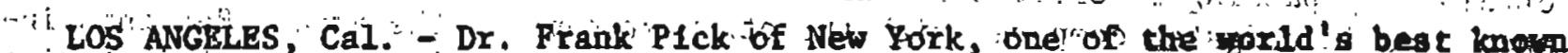
authoritles on curreticies and gold, was in 'Los Angeles-recenti'y conducting a sentnax

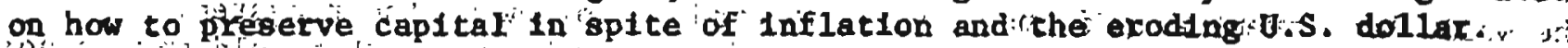

b): While there he told an aidfence that within 20 to 24 months be foresees the

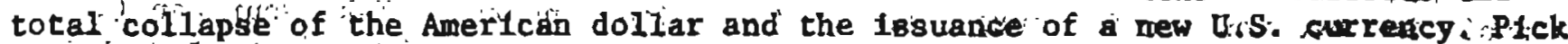
also bald "silver is golng to go up and its position is excellent. He predicted. silver at $\$ 8$ to $\$ 12$ an ounce withln two years.

Vi:jaza

He recommended Iong term allver futures contracts: $15 \mathrm{~s}$

$\therefore$

"The riak is that in the violent declines of the market-and you w11, get about two a year-that you w111 be wiped out. But, a risk 11ke that can be taken, $!$ he $]^{\prime r}$ sold.

"If you now have silver contracta of near explration; transfer to s11ver far the iong run. Thlak "about two contractg-one long, one short, for one year. I l can hardly lose on this silver gambte."

Whil' gold has been attractive to Arab countries, Plck said there bas refeptly been $a$ switch to diamonds.

"The princes of Ruwalt; Saudia Arabla,:Syr1a.and.Iraq have gold, but they, say It takes a lot of watching. Their dollar income continues to increase so they now are golng liato diamoada.

"They buy what are called the unopened DeBeers packets of raw dianonds (abput the size of a match book for five carats)whlch are $\$ 350,000$. These now are Bold, at 25 per cent prentum over that price on the West 47 th Street diamond eeptef 10 ,

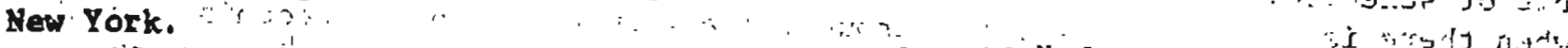

of the other two preclous metals, Dr. Pick said "If you have gutg spunght have one in palladiuin. And If you don't get seaslck, platinum fufures are very good:"

SMOG CONTROL NEEDS COULD BOOST DPMAND FOR PLATINUM, BUREAD REPORT. NOTES

(Department of the Interior -" May 1:5, 1973)

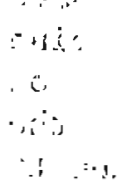

Domestfic demand for platinim could triple overnight if the catalytic muffler becoms the standard automobile exhaust control devica; rccording to a nort Just published, by the Interfor Departinent's Bureau of Hace. Coples: are on sale at the Goverupent Printing office:

of the yarious exhaust cóntrol technlques now being atudled hy: government and Industry researchers, elatinum-baged catalyst system appears to have the best features for conventional gasoline englnes. The catalytic action of the plattpum afiminates most of the carbon monoxide and'imbirned hydrocaxbons in che exbaust. According to the Bureau report, "Jach -device would tequire about, a teath of :

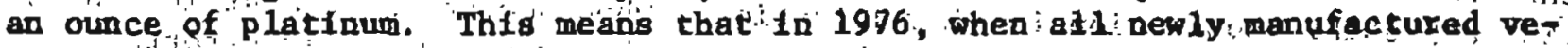
hicles are supposed to have antipollutlon equtpment, ilimost millon and a half ounceg of platinum could be needed for the manufacture of catalytic mufflers.

Profections in the Bureau report were based ont the Environental Protection Agency's 1975 auto etilsstón standards, which heve stnce been postponed to 1976. The delay only moves the ates of the projections ahead by one year, the Bureau noted, without substantially changing the figures themselves. 
Normally the country uses about 500,000 ounces of platinum each year, threefourths of which $1 \mathrm{~s}$ recycled. For the first few years of production of exhaus control equipment, all of the platlaum used would have to be new meta1. Demand would peak 1a 1980, according to Bureau experts.

After that, man of the earliest exhaugt control devices would reach their 50,000-mile operattional limies and would be turned in for recycling. Demand for new platinum would decline, and by 1990, salvaged emission control equipment might provide as much as three-fourths of the platinum needed for new equipment.

- Even so, automoblle manufacturers would continue to need large quantities of new platinum each year. In addition, platinum is necessary in the manufacture of lead-free gasoline; the:only kind that can be used In cars with platinum-catalyst mufflers. So the petroleum industry's consumption of the prectous metal can also be expected to rise in coming years.

The U.S. produces a very IIttle platinum. Roughly 98 percent of world production comes from three countries: In 1972 the Republic of South Africa supplied us with 899,000 ounces, the USSR furnished 720,000 ounces, and 172,000 ounces came Erom Canada.

These totals combined would hardly more than flll anticlpated U.S. ant1pollution requirements for 1976. Data in the Bureau report indicate, however, that production can be increased to meet foreseeable antipollution needs. South Africa, In particular, has $x$ tch undeveloped sources of platinut and could probably boogt its production to two or three rillion ounces a year.

Platinum producers' prices have remalned falrly stable over the past five years, ranging from $\$ 130$ to $\$ 155$ per troy ounce. The use of platinum in ant:pollution devices might not drastically alter this situation, the Bureau safd, becauge in order to hold new customers over the long term, platinum producers would have to be able to offer price stability.

Bureau of Mines Information Cixcular 8565, "Demand for Platlaum to Reduce Pollution from Automobile Exhausts, "by David J. Kusler, can be obtained for $\$ .55$ from the Superfutendent of Documents, U.S. Government Printing Office, Washington, D.C. 20402. Orders should specify catalog number 128.25:8565, and stock number 2404-01212: The report is not sold by the Bureau of Mines.

\section{DIVISION OPEN=FILE REPORTS AVATLABLE}

The following open-file reports are available for public examination at Alaska Division of Geological and Geophysical Surveys offices at: Malntenance Bullding, Unlvèrglty of Alaska; 323 East Fourth Avenue, Anchorage; Room 509 Goldstein Building, 'Junéu and Room 312, 306 Matí Street, Ketchikan, Alaska.

Copies may be obtalned by sending prepayment directly as follows: AOF-35 is avałlable from Technical Supply,729 First Street, Fairbants, Alaska 99701 , telephone 456-4982 and $A O F-37$ is avallable from McCauleys Reprographics, Inc., 721 Gaffney Road, Palrbanks, Alaska 99701, telephone 456-4400. Prices are listed with title below.

\section{TITLE}

Open-File No.

AOF-35

Coal Reserves Study - Chuitna-Beluga-Capps Area, 5 p. text, Geolog1c map and three cross sections. (\$3.75)

AOR-37 Preliminary geochemical anomaly maps of Southeast Ambler River and part of Survey Pass Quadrangles, Alaska, 2 maps, Scale $1: 63,360 \quad(\$ 2.00)$ 
in:

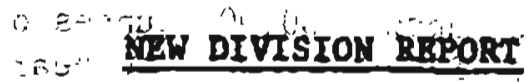

The Alagka Divialon of Geologicar and Ceophysical survays, Departennt of Natural Resources, has relenged the publlcation: Gologic Roport Ho. 36 -

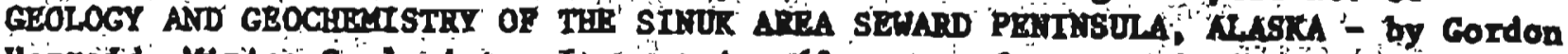

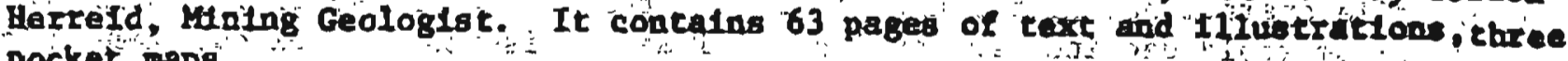
pocket iaps.

The report 18 \$1,00 and hay be obtalned from thid Division of Geologien Geophysteal survays, P.0. Box 80007, Coilege, Alatie 99701 ;"323 Bant Pourth

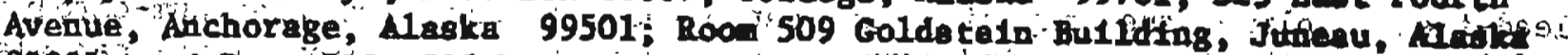

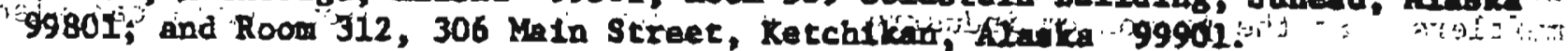

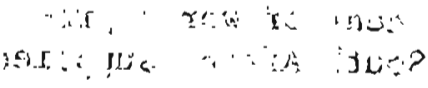

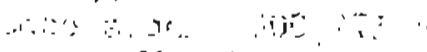

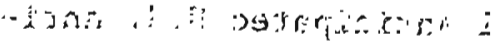

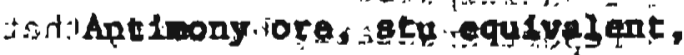

:

tBarlte (drifiding wad grada per con)

Beryil1em porder, 987, per $1 \mathrm{~b}$.

Chrome ore pertlong ton

Copper per 16.

f. . Cold per oz.

Leed per $1 \mathrm{~b}$.

Mercury per :76f flask

Molybdenum conc. per $1 \mathrm{~b}$.

Nfcke1 per 1b.:(cathode)

Platimu per oz.

StIver, New York, per or.

TIn per Ib., New Tork

Titanium ore per ton (Ilmentte)

Tungaten per uait

Zinc per $1 \mathrm{~b}$.

\section{MBTLL MARKET}

Aurust 24,1973

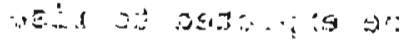

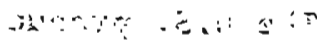

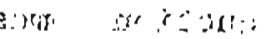

Eonth too

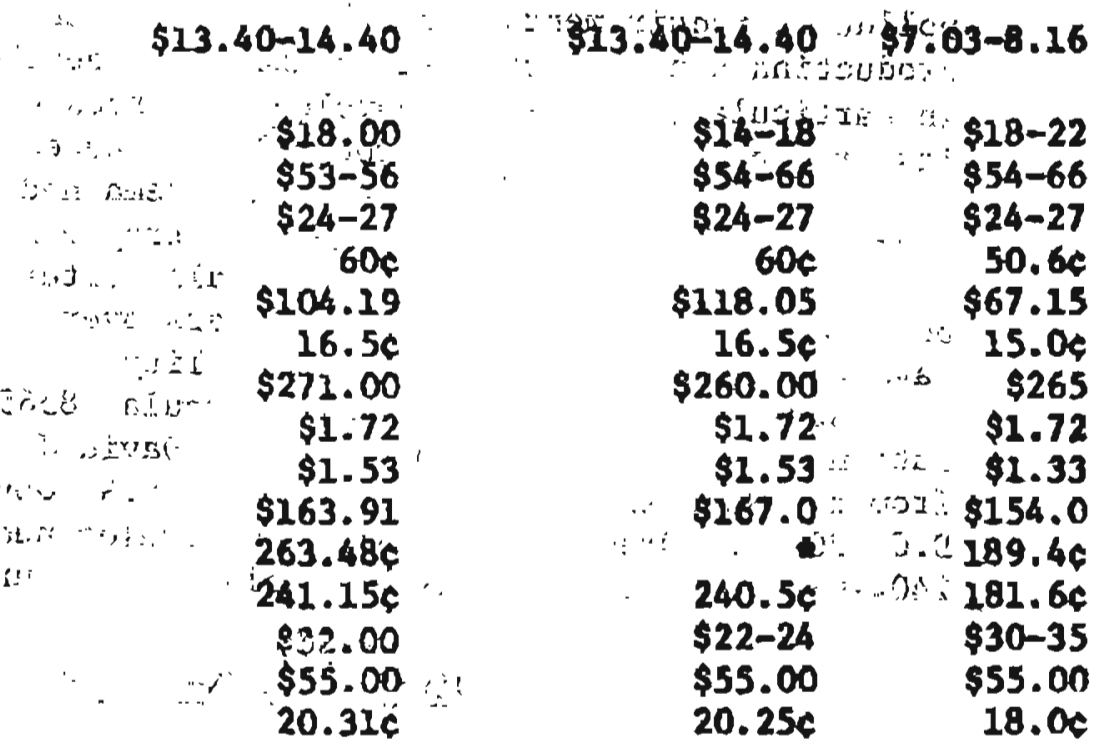

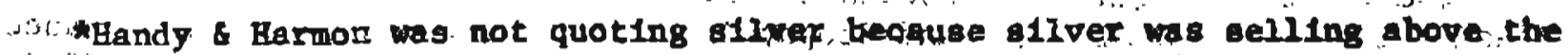

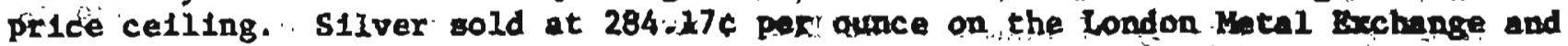
291.94 per ounce on the New York comodtty exchange', lat. pop (c).
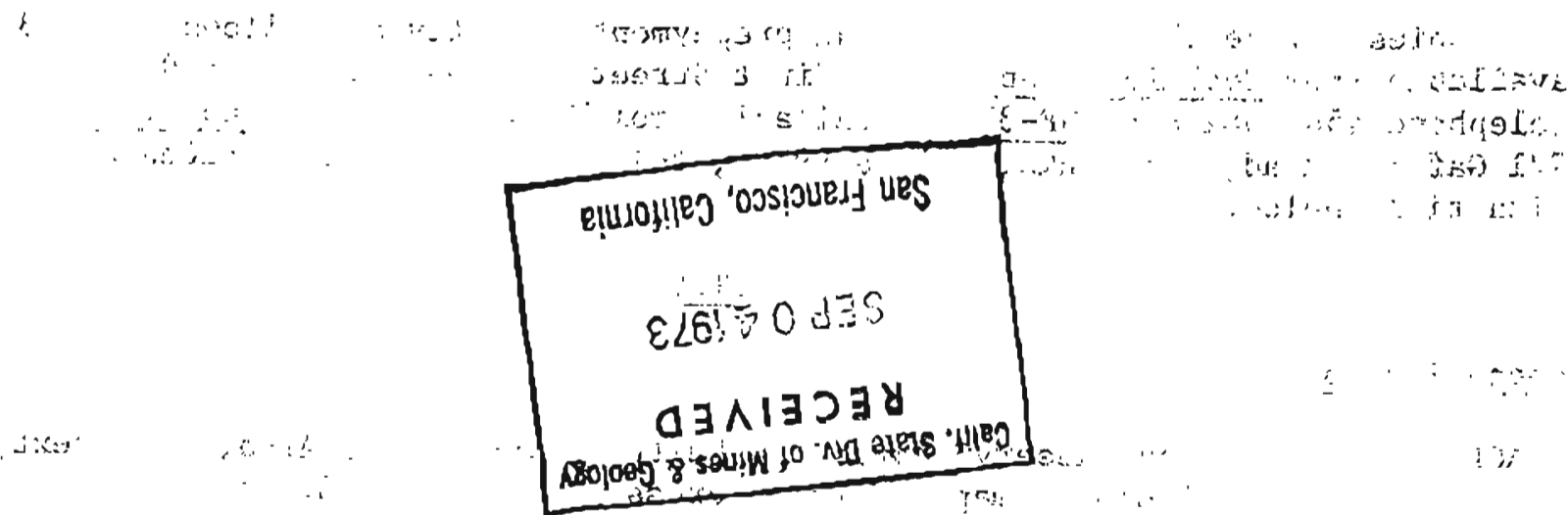